I Komang Ardana. (2019). Penerapan Model Pembelajaran Kontekstual Berbantuan LKS untuk Meningkatkan Aktivitas dan Hasil Belajar Produk Kreatif dan Kewirausahaan. Jurnal Penelitian dan Pengembangan Pendidikan. Vol. 3 (1) pp. 37-42.

\title{
Penerapan Model Pembelajaran Kontekstual Berbantuan LKS untuk Meningkatkan Aktivitas dan Hasil Belajar Produk Kreatif dan Kewirausahaan
}

\author{
I Komang Ardana*
}

SMK Negeri 2 Singaraja, Buleleng-Bali

\begin{abstract}
Abstrak
Tujuan dari diadakannya penelitian ini adalah untuk mengetahui peningkatan aktivitas dan hasil belajar siswa setelah diterapkan pendekatan pembelajaran kontekstual dengan berbantuan LKS pada Pembelajaran Produk Kreatif dan Kewirausahaan Kelas XI Akomodasi Perhotelan 3 SMK Negeri 2 Singaraja Tahun Pelajaran 2018/2019. Penelitian ini adalah penelitian tindakan kelas (PTK). Subjek penelitian ini adalah siswa kelas XI Akomodasi Perhotelan 3 SMK Negeri 2 yang berjumlah 35 orang yang terdiri atas 13 orang siswa Perempuan dan 22 orang siswa Laki-laki. Penelitian dilakukan pada semester I (ganjil) tahun pelajaran 2018/2019. Penelitian ini dilaksanakan di SMK N 2 Singaraja, Kecamatan Buleleng, Kabupaten Buleleng. Objek dari penelitian tindakan ini adalah pembelajaran kontekstual, media LKS, Aktivitas dan Hasil belajar siswa. Data aktivitas belajar siswa dikumpulkan dengan menggunakan lembar observasi aktivitas belajar siswa yang telah dipersiapkan, sedangkan data hasil belajar siswa yaitu menggunakan tes. Analisis data yang digunakan pada penelitian ini menggunakan analisis data deskriptif. Berdasarkan analisis data yang dilakukan dapat disimpulkan bahwa implementasi model pembelajaran kontekstual berbantuan LKS dapat meningkatkan aktivitas dan hasil belajar produk kreatif dan kewirausahaan kelas XI Akomodasi Perhotelan 3 SMK Negeri 2 Singaraja Tahun Pelajaran $2018 / 2019$
\end{abstract}

\section{PENDAHULUAN}

Undang-undang No.14 Tahun 2005 secara gamblang dijelaskan bahwa Guru adalah pendidik profesional dengan tugas utama mendidik, mengajar, membimbing, mengarahkan, melatih, menilai, dan mengevaluasi peserta didik pada pendidikan anak usia dini jalur pendidikan formal, pendidikan dasar, dan pendidikan menengah.

Dalam penjelasan Pasal 7 PP Nomor 29 Tahun 1990 menyatakan bahwa SMK menyelenggarakan program pendidikan yang disesuaikan dengan jenis-jenis lapangan pekerjaan. Sesuai dengan yang tertera dalam kurikulum SMK 1994, siswa diharapkan memiliki keterampilan yang bersifat produktif prosedural sesuai dengan kebutuhan dunia kerja. Sehubungan dengan hal tersebut, program pendidikan SMK dikelompokkan menjadi 6 yaitu kelompok pertanian dan kehutanan, teknologi dan industri, bisnis manajemen, kesejahteraan dan masyarakat, dan seni dan kerajinan serta kelompok pariwisata.

Berdasarkan hasil refleksi awal yang dilakukan pada bulan 12 Agustus 2018 di SMK Negeri 2 khususnya di kelas XI Akomodasi Perhotelan 3 pada saat proses pembelajaran Produk Kreatuf dan Kewirausahaan ditemukan suatu permasalahan, Dalam pembelajaran tersebut hanya terjadi komunikasi satu arah antara guru dengan siswa, guru lebih banyak menggunakan metode ceramah sehingga siswa belum dapat membangun secara utuh pengetahuan yang didapat melalui pengalaman nyata dan siswa belum mampu menemukan hasil dari proses berpikir sendiri. Di samping itu, guru belum efektif

* Corresponding author.

E-mail Addresses: - ikomangardana164@gmail.com (I Komang Ardana) 
menggunakan keterampilan bertanya dasar dan lanjut sehingga informasi yang disampaikan belum lengkap sehingga siswa tidak menemukan konsep materi yang dipelajarinya.

Pada akhir pembelajaran guru belum secara maksimal melaksanakan kegiatan refleksi dalam proses pembelajaran. Kegiatan refleksi sangat berguna bagi siswa untuk mengingat kembali apa yang telah dipelajari dan mengadakan penilaian perhatian guru hanya tercurah kepada perkembangan aspek intelektual saja. Hal inilah yang menyebabkan interaksi siswa rendah, dan berdampak pada hasil belajar siswa yang baru mencapai ketuntasan $65 \%$, belum mencapai ketuntasan belajar $80 \%$. Berdasarkan pengamatan pada kegiatan pengajaran Kewirausahaan hanya 20 orang siswa yang baru mencapai nilai kriteria ketuntasan minimal (KKM) 80,00 dari 35 orang siswa yang berada di kelas XI.

Berdasarkan pengalaman refleksi di atas dapat disimpulkan bahwa pelaksanaan pembelajaran Produk Kreatif dan Kewirausahaan di kelas XI Akomodasi Perhotelan 3 perlu dilakukan perbaikan untuk mencapai hasil sesuai dengan standar kompetensi. Perbaikan pembelajaran akan dilakukan dengan mengikuti prosedur penelitian tindakan kelas.

Masalah dalam penelitian ini yaitu rendahnya Aktivitas dan Hasil belajar siswa kelas XI Akomodasi Perhotelan 3 di SMK Negeri 2 Singaraja diatasi dengan menerapkan pendekatan pembelajaran kontekstual berbantuan LKS. Pendekatan pembelajaran kontekstual merupakan suatu konsep belajar dimana guru menghadirkan situasi dunia nyata ke dalam kelas dan mendorong siswa membuat hubungan pengetahuan yang dimilikinya dengan penerapannya dalam kehidupan mereka sebagai anggota keluarga dan masyarakat. Dengan konsep itu, hasil pembelajaran diharapkan lebih bermakna bagi siswa. Proses pembelajaran berlangsung alamiah dalam bentuk kegiatan siswa bekerja dan mengalami, bukan transfer pengetahuan dari guru ke siswa. Hasil pembelajaran diharapkan lebih bermakna bagi anak untuk memecahkan persoalan, berpikir kritis dan melaksanakan observasi serta menarik kesimpulan dalam kehidupan jangka panjang.

Belajar adalah merupakan suatu proses, suatu kegiatan dan bukan suatu hasil atau tujuan. Belajar bukan hanya mengingat, akan tetapi lebih luas daripada itu, yakni mengalami. Hasil belajar bukan suatu penguasaan hasil latihan melainkan perubahan kelakuan" (Hamalik, 2005: 37). Belajar ialah suatu proses usaha yang dilakukan seseorang untuk memperoleh suatu perubahan tingkah laku yang baru secara keseluruhan, sebagai hasil pengalamanya sendiri dalam interaksi dengan lingkunganya" (Slameto, 2003:2). Dampak pengajaran adalah hasil yang dapat diukur dengan segera atau secara langsung. Sedangkan dampak pengiring adalah hasil belajar siswa yang tampak secara tidak langsung atau merupakan transfer hasil belajar" (Dimyati dan Mudjiono, 2006:295). Jadi dapat disimpulkan hasil belajar adalah sesuatu yang dicapai atau diperoleh siswa berkat adanya usaha atau pikiran yang mana hal tersebut dinyatakan dalam bentuk penguasaan, pengetahuan dan kecakapan dasar yang terdapat dalam berbagai aspek kehidupan sehingga nampak pada diri indivdu penggunaan penilaian terhadap sikap, pengetahuan dan kecakapan dasar yang terdapat dalam berbagai aspek kehidupan sehingga nampak pada diri individu perubahan tingkah laku secara kuantitatif (Setiawan Hendri, 2014).

Melalui pendekatan pembelajaran kontekstual guru dapat mengaitkan materi pelajaran dengan dunia nyata siswa untuk membuat hubungan antara pengetahuan yang dimiliki dengan penerapannya dalam kehidupan sehari-hari, siswa dapat berdiskusi dengan teman secara berkelompok, siswa dapat menemukan setiap materi yang dipelajari, guru dapat menggunakan media untuk mempermudah pemahaman siswa mengenai materi yang disampaikan, siswa masih mengingat apa yang telah dipelajari dan penilaian dapat ditekankan pada semua aspek tidak hanya aspek intelektual saja. Diharapkan dengan menerapkan pendekatan pembelajaran Kontekstual dengan Berbantuan LKS diharapkan Aktivitas dan Hasil belajar siswa akan meningkat.

Berdasarkan latar belakang tersebut maka dilakukan penelitian tindakan yang berjudul: "Penerapan Model Pembelajaran Kontekstual Berbantuan LKS untuk Meningkatkan Aktivitas dan Hasil Belajar Produk Kreatif dan Kewirausahaan Kelas XI Akomodasi Perhotelan 3 SMK Negeri 2 Singaraja Tahun Pelajaran 2018/2019".

\section{METODE PENELITIAN}

Penelitian ini adalah tindakan kelas yang dilakukan dari bulan Agustus s/d Desember 2018 bertempat di SMK Negeri 2 Singaraja. Waktu penelitian dari bulan Agustus sampai dengan bulan Nopember 2018 dan pelaporan bualan Desember 2018.

Subjek penelitian ini adalah siswa kelas XI Akomodasi Perhotelan 3 SMK Negeri 2 yang berjumlah 35 orang yang terdiri atas 13 orang siswa Perempuan dan 22 orang siswa Laki-laki. Penelitian dilakukan pada semester I (ganjil) tahun pelajaran 2018/2019. Objek dari penelitian tindakan ini adalah pembelajaran kontekstual, media LKS, Aktivitas dan Hasil belajar siswa. 
Pendekatan kontekstual merupakan proses belajar yang mengaitkan materi pelajaran dengan kenyataan atau konteks kehidupan pribadi siswa. Dengan demikian proses pembelajaran yang mereka lakukan lebih bermakna karena berhubungan dengan pengalaman mereka sehari-hari. Dalam hal ini pembelajaran tidak hanya mentransfer pengetahuan dari guru ke siswa, tetapi siswa diarahkan untuk memaknai apa yang mereka pelajari. Sehingga siswa dapat memahami apa yang mereka pelajari dan mengambil manfaat dari pelajaran tersebut untuk diterapkan dalam kehidupan mereka sehari-hari. Sebuah kelas dikatakan menggunakan pendekatan kontekstual jika menerapkan ketujuh komponen tersebut dalam pembelajaran. Dengan memperhatikan tujuh komponen utama pendekatan kontekstual diharapkan guru dapat menerapkannya dalam praktek pembelajaran di kelas. Sehingga dari penerapan pendekatan kontekstual diharapkan semua siswa mampu membangun dan menemukan sendiri pengetahuan dan keterampilannya, melalui proses bertanya, kerja kelompok, belajar dari model sebenarnya, dan merefleksinya dalam kehidupan sehari-hari.

Pembahasan di atas maka pendekatan konstekstual dapat diterapkan dalam materi menganalisis peluang usaha dan menganalisis aspek-aspek peencanaan usaha.Untuk lebih jelasnya disampaikan perencanaan pembelajaran pada setiap siklus dengan menggunakan pendekatan konstekstual.

a. Konstruktivisme: guru membangun pengetahuan siswa mengenai materi menganalisis peluang usaha

b. Menemukan (Inquiry) : pada siklus ini guru menyediakan tiga LKS yang harus dikerjakan siswa secara berkelompok mengenai pengelompokan materi menganalisis peluang usaha. Sehingga dari pengerjaan LKS dapat memacu siswa untuk menemukan dan mencari tahu jawabannya sendiri pada diri mereka sendiri.

c. Bertanya (Questioning): kegiatan bertanya dapat diterapkan antar guru dengan siswa seperti terlihat pada saat mengkonstruksi pengetahuan siswa atau di akhir pembelajaran guru dapat mengajukan pertanyaan mengenai materi yang telah disampaikan untuk mengetahui pemahaman siswa. Sedangkan kegiatan bertanya antara siswa dengan guru dapat dilakukan ketika siswa mengalami kesulitan atau tidak paham tentang suatu hal. Selain itu kegiatan bertanya dapat dilakukan antara siswa dengan siswa dengan cara berdiskusi, bekerja dalam kelompok dan sebagainya.

d. Masyarakat Belajar (Learning Community): guru mengelompokkan siswa dalam kelompok belajar.

e. Pemodelan (Modeling): guru melakukan pemodelan dengan menggunakan LKS.

f. Refleksi (Reflection): guru mengajukan pertanyaan tentang apa saja yang telah didapatkan siswa pada hari itu, dan guru menyimpulkan materi yang telah dibahas.

g. Penilaian yang sebenarnya (Authentic Assessment): guru melakukan tes dan menilai hasil kerja kelompok siswa.

Dalam Penelitian ini akan dikembangkan perangkat pembelajaran meliputi rencana pembelajaran dan tes hasil belajar. Dalam penelitian ini akan direncanakan dalam 2 siklus. Rancangan Penelitian Tindakan Kelas yang dapat diterapkan yaitu model Kemmis dan Mc. Targat (dalam Kasihani, 1998: 114). Bahwa dalam satu siklus terdiri dari empat langkah, yaitu: (1) perencanaan, (2) pelaksanaan, (3) observasi/evaluasi, dan (4) refleksi.

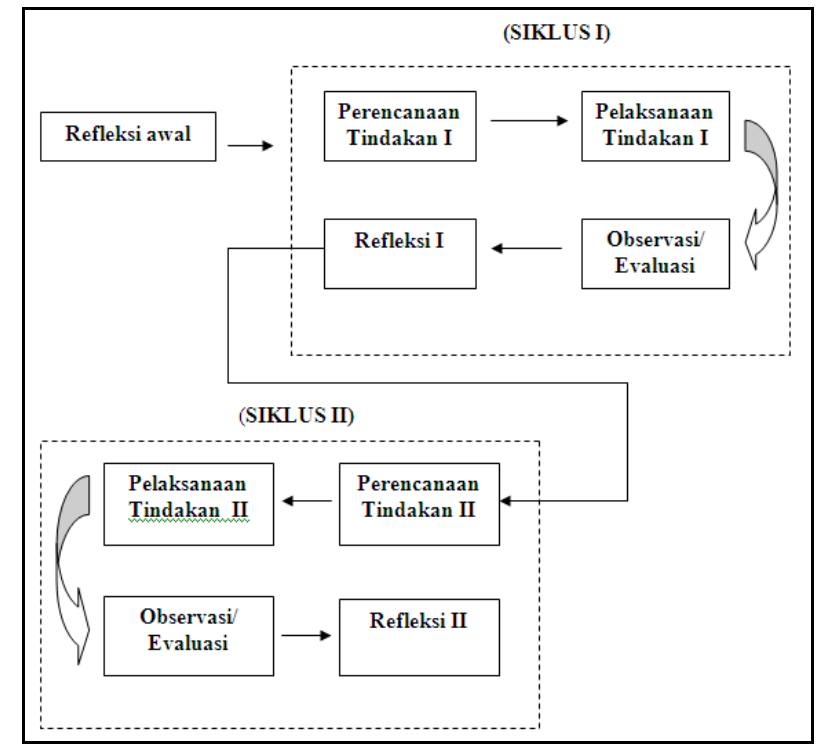

Gambar 1. Siklus PTK 
Observasi dilakukan dengan menggunakan lembar observasi aktivitas belajar siswa yang telah dipersiapkan. Untuk mengetahui hasil belajar siswa maka dilaksanakan tes hasil belajar dalam bentuk tes. Metode tes (Agung, 1999: 75) adalah cara memperoleh dan yang berbentuk suatu tugas yang harus dikerjakan oleh seorang atau sekelompok orang yang di tes (teessee) dan dari tes dapat menghasilkan suatu skor dan selanjutnya dibandingkan dengan kriteria atau standar tertentu. Pada umumnya tes itu banyak digunakan untuk mengukur ranah kognitif. Namun bisa juga untuk mengukur ranah afektif maupun psikomotor. Instrumen pengumpulan data yang digunakan adalah butir-butir soal atau instrumen soal yang mengukur hasil belajar siswa pada pembelajaran Produk Kreatif dan Kewirausahaan. Butir-butir soal atau instrumen soal diambil dari buku paket dan LKS Produk Kreatif dan Kewirausahaan.. Setelah data aktivitas belajar dan hasil belajar siswa terkumpul, selanjutnya dilakukan analisis data dengan menggunakan analisis deskriptif kuantitatif.

\section{ANALISIS DAN PEMBAHASAN}

Sebelum melaksanakan kegiatan pembelajaran siklus I, peneliti terlebih dahulu melakukan sosialisasi tentang model pembelajaran Konteskstual berbantuan LKS, dan dilanjutkan ke siklus II. Pada tanggal 6 Agustus 2018 peneliti dan guru melakukan kegiatan sosialisasi dan pre test kepada siswa kelas XI Akomodasi Perhotelan 3 SMK N 2 Singaraja untuk menerapkan model pembelajaran Kontekstual berbantuan LKS. Kegiatan sosialisasi terpisah dari siklus tindakan, yaitu waktu yang digunakan dalam kegiatan sosialisasi selama 2 jam pelajaran.

Pada saat sosialisasi, peneliti terlebih dahulu menginformasikan kepada semua siswa bahwa kegiatan pembelajaran model pembelajaran Kontekstual berbantuan LKS ini diterapkan dalam pembelajaran Mata Pelajaran Produk Kreatif dan Kewirausahaan melalui pelaksanaan siklus I dan dilanjutkan ke siklus II. objek penilaian Hasil Belajar dan aktivitas Siswa. Penilaian hasil belajar diperoleh dari tes akhir pembelajaran yang dilaksanakan pada setiap akhir siklus, masing-masing terdiri dari soal essay dan lembar observasi.

Perkembangan aktivitas belajar siswa pertemuan siklus I dengan perkembangan aktivitas belajar siswa meningkat pada setia pertemuan siklus I dengan kualifikasi cukup aktif sedangkan pada akhir siklus rata-ratanya sebesar 57,14 dengan kualifikasi cukup aktif, sehingga aktivitas belajar siswa dalam siklus I belum memenuhi kualifikasi keberhasilan yaitu kualifikasi aktif.

Analisis data hasil belajar pada siklus I menunjukkan bahwa tes hasil belajar siswa rata-rata 57 dengan Ketuntasan Klasikal (KK) sebesar 28,57\% . Banyaknya siswa yang tuntas atau dapat memenuhi KKM yaitu sebanyak 10 orang dan siswa yang belum memenuhi KKM sebanyak 25 orang. Untuk pencapaian nilai hasil belajar, masih ada beberapa siswa yang tidak memenuhi KKM. Hal ini dipengaruhi kebiasaan siswa yang kurang aktif dalam mengikuti pembelajaran sehingga perlu adanya penekanan terhadap penilaian hasil belajar yang diterapkan dalam pelaksanaan tindakan.

Berdasarkan hasil refleksi maka perlu adanya perbaikan penerapan model pembelajaran kontekstual pada siklus II untuk memperoleh hasil yang lebih optimal. Pelaksanaan siklus II diadakan upaya-upaya perbaikan sesuai dengan kekurangan-kekurangan yang dialami selama pelaksanaan siklus I. Adapun upaya-upaya perbaikan yang dilakukan antara lain sebagai berikut:

1) Menjelaskan kembali melalui sosialisasi tentang model pembelajaran kontekstual berbantuan LKS pada siswa. Sosialisasi tersebut diharapkan agar siswa lebih tertarik dan terbiasa untuk mengikuti kegiatan pembelajaran.

2) Siswa lebih dimotivasi untuk mengemukakan pendapat, pertanyaan, ataupun tanggapannya. Selain itu, dijelaskan pula pada siswa bahwa salah dalam mengemukakan pendapat, pertanyaan, ataupun tanggapan itu hal biasa, sehingga siswa tidak perlu merasa takut saat mengemukakan pendapat, pertanyaan, ataupun tanggapan.

3) Setiap kelompok siswa diarahkan untuk mengadakan pembagian tugas dalam melakukan penemuan, sehingga tidak ada anggota kelompok yang diam ataupun bercanda.

4) Siswa diarahkan untuk membaca petunjuk yang ditulis dalam LKS sebelum siswa menjawab LKS. Hal tersebut diharapkan siswa dapat memanfaatkan LKS secara lebih optimal sebagai pemandu dalam mengerjakan tugas.

5) Mengarahkan kelompok untuk saling bekerjasama, dengan membagi tugas setiap siswa agar semua anggota kelompok memiliki peran untuk bekerja di dalam kelompoknya.

6) Siswa diarahkan untuk membaca rubrik penilaian unjuk kerja yang akan digunakan untuk menilai proses pembelajaran praktikum yang akan dilaksanakan, yang ada pada LKS. Dengan demikian diharapkan siswa siap melakukan praktikum. 
Mengoptimalkan peran guru dan peneliti dalam pelaksanaan tindakan dalam pengelolaan kelompok, sehingga pada siklus II dapat dilakukan tindakan yang lebih optimal dan lebih aktif. Pada siklus II nilai aktivitas belajar siswa meningkat tiap pertemuan pada siklus II. Kualifikasi untuk siklus II mencapai kualifikasi sangat aktif dengan presentase 85.71\%Berdasarkan kualifikasi keberhasilan penelitian, ini dikatakan berhasil apabila aktivitas belajar siswa mencapai kualifikasi aktif. Sehingga pelaksanaan pada tindakan siklus II sudah berhasil dilihat dari segi aktivitas belajar siswa. Berdasarkan hasil analisis data hasil belajar siswa pada siklus II, diperoleh nilai rata-rata 81.08 dengan kualifikasi memenuhi KKM, sedangkan ketuntasan klasikal memperoleh nilai $85.71 \%$ dengan kategori memenuhi KKM. Berdasarkan kualifikasi penelitian, dikatakan berhasil jika nilai ketuntasan klasikal minimal $\geq 85 \%$. Dari kualifikasi tersebut, hasil belajar siswa pada siklus II sudah dapat dikatakan berhasil.

Berdasarkan analisis rata-rata aktivitas siswa dan hasil belajar pada siklus I, yaitu adanya peningkatan nilai hasil belajar pada tiap pertemuan, tetapi ada beberapa siswa yang masih belum memenuhi Kriteria Ketuntasan Minimal (KKM) mengacu pada kriteria penilaian yang berlaku di SMK N 2 Singaraja dalam Pembelajaran Kewirausahaan dan belum tercapai ketuntasan klasikal sesuai dengan kriteria keberhasilan yang di tetapkan pada siklus I.

Nilai rata-rata aktivitas siswa pada siklus I diperoleh 57,14 kualifikasi cukup aktif dan dengan jumlah siswa yang tidak aktif sebanyak 0 orang siswa yang mendapakan kualifikasi kurang aktif 5 orang, kualifikasi cukup aktif 20 orang, kualifikasi aktif. 7 orang, kualifikasi sangat aktif 3 orang. Sedangkan untuk data hasil belajar siklus I yaitu 10 siswa yang tuntas dan siswa yang belum memenuhi KKM atau belum tuntas sebanyak 25 orang, sehingga ketuntasan klasikal yang dicapai 28,37\% dengan kualifikasi ketuntasan klasikal belum tuntas atau tidak memenuhi KKM.

Dari kualifikasi tersebut, pelaksanaan tindakan siklus I belum mencapai kualifikasi keberhasilan karena ketuntasan klasikal belum berhasil. Ketidak berhasilan disebabkan oleh beberapa permasalahan yang terjadi selama pelaksanaan dalam siklus I, seperti siswa pada saat mengikuti pembelajaran masih kurang disiplin. Siswa masih bekerja secara individu atau kerjasama dalam kelompok kurang dalam menyelesaikan permasalahan yang diberikan oleh guru. Selain itu, kemampuan siswa dalam kelompok rata-rata sama sehingga kelompok bersifat homogen. Siswa juga belum mampu menguraikan proses dalam memecahkan masalah, dan siswa juga belum terbiasa untuk mengemukakan pendapat, menjawab pertanyaan, maupun bertanya tentang materi yang belum dipahami.

Hal ini menyebabkan siswa terlihat kurang aktif dalam pembelajaran di kelas. Kendala-kendala yang didapatkan kemudian didiskusikan oleh guru dan peneliti dalam kegiatan refleksi untuk dicarikan solusinya. Melalui kegiatan refleksi ini, disepakati beberapa solusi yang akan dilaksanakan untuk mengatasi kendala-kendala dalam pembelajaran. Siswa diharapkan mampu menemukan konsep sehingga konsep tersebut akan lebih melekat dalam struktur kognitif siswa. Agar siswa benar-benar bisa memahami materi dan praktek dengan benar, maka siswa perlu diberikan suatu situasi atau kondisi belajar yang kondusif, relevan dengan kehidupan nyata dan terstruktur.

Perbaikan tindakan pada siklus I memperbaiki pembelajaran pada siklus II, sehingga diperoleh peningkatan aktivitas belajar siswa pada siklus II diperoleh Nilai rata-rata hasil belajar siswa pada siklus II diperoleh sebesar 85,71 sangat aktif, 14,28 aktif dengan kualifikasi memenuhi KKM dan dengan ketuntasan klasikal sebesar $85.71 \%$ dengan kualifikasi memenuhi KKM. Berdasarkan kriteria keberhasilan, suatu penelitian dikatakan berhasil apabila kualifikasi nilai ketuntasan klasikal minimal $\geq 85 \%$. Dengan demikian, pelaksanaan tindakan pada siklus II sudah bisa dikatakan berhasil.

\section{KESIMPULAN}

Berdasarkan hasil penelitian tindakan kelas yang telah dilakukan dengan menggunakan model pembelajaran kontekstual pada mata pelajaran Kewirausahan Berbantuan Lembar Kerja Siswa (LKS), maka dapat ditarik kesimpulan sebagai berikut:

1. Model pembelajaran kontekstual dapat peningkatkan aktivitas belajar siswa pada mata Pelajaran Produk Kreatif Kewirausahaan di kelas XI Akomodasi Perhotelan 3 dapat meningkatkan aktivitas belajar siswa yaitu 57,14 \% siklus I kualifikasi cukup aktif menjadi 85,71 \%pada siklus II kualifikasi sangat aktif.

2. Model pembelajaran kontekstual dapat peningkatkan hasil belajar siswa pada mata Pelajaran Pelajaran Produk Kreatif Kewirausahaan di kelas XI Akomodasi Perhotelan 3 dapat meningkatkan hasil belajar siswa. Ketuntasan hasil belajar klasikal yaitu 28,57 siklus I, ketuntasan klasikal menjadi 85,71 pada siklus II memenuhi KKM.

Mengacu kepada hasil temuan penelitian ini, dapat dikemukakan beberapa saran sebagai berikut: 
1. Disarankan kepada guru-guru SMK Negeri 2 Singaraja agar dalam mengajar Kewirausahaan menggunakan Kontekstual berbantuan LKS yang dapat meningkatkan hasil belajar peserta didik, sehingga tidak lagi adanya strategi belajar yang monotun yang menyebabkan terjadinya kebosanan siswa.

2. Disarankan kepada peneliti lain agar dapat mengangkat variable lain, yang belum terjangkau dalam penelitian ini.

\section{DAFTAR PUSTAKA}

Agung, A.A. Gede. 1991. Metodologi Penelitian Pendidikan. Singaraja: Sekolah Tinggi Keguruan dan Ilmu Pendidikan.

Barlia, Lily. 2006. Mengajar dengan Pendekatan Lingkungan Alam Sekitar: Bab IV. Jakarta: Departemen Pendidikan Nasional.

Dimyati dan Mudjiono. 2006. Belajar dan Pembelajaran. Jakarta: Rineka Cipta.

Hamalik 0. 2005. Proses Belajar Mengajar. Jakarta: PT Bumi Aksara.

Koyan, I Wayan. 2009. Statistik Dasar dan Lanjut (Teknik Analisis Data Kuantitatif). Singaraja: Program Studi Penelitian dan Evaluasi Pendidikan Program Pasca Sarjana Universitas Pendidikan Ganesha.

Sanjaya, Wina. 2010. Strategi Pembelajaran Berorientasi Standar Proses Pendidikan. Jakarta: Prenada Media Group.

Setiawan, Hendri. 2014. Penerapan Model Pembelajaran Kooperatif tipe NHT (Numbered Head Together) untuk meningkatkan Aktifitas dan Hasil Belajar teknik dasar passing bola basket pada siswa kelas VII SMPN 1 Sukasada. Jurnal PJOK Undiksha. Vol 2, No1.

Slameto. 2003. Belajar dan Faktor-Faktor yang Mempengaruhinya. Jakarta: PT. Rineka Cipta. 